\title{
PRELIMINARY SURVEY OF BIODIVERSITY OF BHAGDA TAAL, A WETLAND OF BALRAMPUR, UTTAR PRADESH
}

\author{
VARSHA SINGH ${ }^{\mathrm{a}}$ AND SADGURU PRAKASH ${ }^{\mathrm{b} 1}$ \\ ${ }^{a b}$ Department of Zoology, M.L.K. (P.G.) College, Balrampur, Uttar Pradesh, India
}

\begin{abstract}
The present study is undertaken to assess the biodiversity of naturally occurring Bhagda Taal of Balrampur District of Uttar Pradesh. The said taal is one of the largest natural wetland of this district. It covers an area of about $\mathbf{1 0}$ ha and is rich in faunal and floristic diversity. To assess the biodiversity of this wetland, a preliminary survey of the taal was carried out during the year 2019 which indicate the rich biodiversity of this pond. The notable animal diversity includes annelids $(6$ species), arthropods (16 species), molluscans (6 species), fishes (21 species), amphibians (3 species), reptiles (2 species) and birds ( 3 species) and zooplanktons were available there. The result also shows the occurrence of 31 hydrophytes. Out of 31 species, 7 belonging to floating weeds, 3 to emergents weeds, 8 to submerged weeds, 8 to marginal weeds and 5 species of green algae and phytoplankton. Looking on the biodiversity of the wetland, it is urgently needed to preserve this waterbody so as to offer a natural abode to the animals, a beautiful habitat to the plants and ecological gifts to the environment.
\end{abstract}

KEYWORDS: Biodiversity, Bhagda Taal, Wetland

As per the definition adopted at Wetlands are areas of marsh, fen, peat land or water, whether natural or artificial, permanent or temporary, with water that is static or flowing; fresh, brackish, or salty, including areas of marine water the depth of which at low tide does not exceed six meters (Ramsar Convention,1971). Wetlands are categorized as inland (also known as non-tidal, freshwater wetlands) and coastal (also known as tidal, salt water or estuarine wetlands) (Barbier et al. 1997). Wetlands are important components of watersheds and provide many valuable functions to environment and to society (Prakash, 2020). Ramsar convention concluded that wetlands are world's most productive environment with stunning biological diversity. Wetlands are often described as "Kidneys of land scope", because of the functions they perform in the hydrological and chemical cycles, and as biological supermarkets, because of the extensive food webs and rich biodiversity they support (Mitsch and Gosselink, 1993).

Wetlands are one of the most productive ecosystems on the earth that provide food and habitat for many aquatic life including threatened and endangered species. So, conservation of wetlands is very much essential as wetlands are one of the most threatened habitats of the world. The most important step for conservation of wetlands is to maintain a proper water quality (Smitha and Shivashankar, 2013). They have been an essential part of human civilization meeting many crucial needs for life such as drinking water, food, fodder, energy supply, flood storage, transport, recreation, biodiversity and climate stabilization. The geomorphologic, climatic, hydrological and biotic diversity across continents has contributed to wetland diversity.

Wetland loss may be defined as the loss of wetland area, due to conversion of wetland to nonwetland areas as a result of human activity and wetland degradation is the impairment of wetland functions as a result of human activity. According to Costanza et al. (1997), the wetland all over the world occupying only $6.5 \%$ of the earth's surface area. About $50 \%$ of the world's wetlands have been lost in the last century, primarily through drainage for agriculture, urban development and water system regulations. On a global scale, the loss of wetlands can be mainly attributed to natural and anthropogenic activities such as shooting population, escalated human activity, unplanned development, absence of management structure, want of proper legislation, and lack of proper awareness regarding the vital roles played by these ecosystems. The loss of wetlands has led to several ecological disasters in some areas, including large-scale devastation due to inundation. The major causes of loss of biodiversity in wetland systems include land use patterns, habitat destruction, pollution, exploitation of resources, and invasive species. Wetlands are under increasing stress due to the rapidly growing population, technological development, urbanization and economic growth. 
The wetlands in India vary from high-altitude Himalayan lakes to the flood plains of the major river systems, from saline and temporary wetlands of the arid and semi-arid regions to coastal wetlands such as lagoons, backwaters and estuaries, mangrove swamps, coral reefs and marine wetlands, and so on. According to the Directory of Asian Wetlands (Scott, 1989), India has a total of 27,403 wetlands, of which 23,444 are inland wetlands and 3,959 are coastal wetlands. Indian wetlands are estimated to occupy $18.5 \%$ of the country's total geographical area of which $70 \%$ of the area is under paddy cultivation. Due to urbanization and anthropogenic pressure most of the wetlands in India are succumbed to greater degree of biologically active nutrient accumulation (Verma and Prakash, 2018).

Some studies have been made by different researchers on the limnology as well as plankton, insect, benthos and fish biodiversity of welands in U.P. during the last few decades such as Prakash et al., (2015), Verma and Prakash (2018 \& 2020), Prakash and Verma (2019), Prakash and Singh (2020), Prakash (2020a,b), Prakash and Yadav (2020) and Ranjan and Kushwaha (2020). Therefore, the present study is aimed to systematic survey on the fish diversity of this taal.

\section{STUDY AREA}

Bhagda Taal is a large shallow lentic waterbody. The total catchment area of wetland is about 10 ha. It is situated in Gurhra (Kushmor) villages, of Shriduttganj Block of Utraula Tahasih of district Balrampur. But in summer season its water spread area becomes reduced up to 7.0 ha. It is situated between the latitude $27^{0} 25^{\prime} 48^{\prime /} \mathrm{N}$ to $27^{0} 43^{\prime} 08^{\prime \prime} \mathrm{N}$, altitude and $82^{\circ} 18^{\prime} 48^{\prime \prime} \mathrm{E}$ to $82^{0} 30^{\prime} 18^{\prime \prime} \mathrm{E}$ longitude. The climatic change influences to its vast openness, landscape ecology and biodiversity. The Taal is enriched with several type of vegetation such as Nymphaea, Nelumbo and Nymphya as well as aquatic birds like Duck, Saras and Bagula. The water of Taal is used for agriculture and fish culture. The abundant food attracts hundreds of resident and migratory birds including Siberian crane during winter season. As an important resort for the native faunal diversity and a beautiful habitat for the phytodiversity, it has never been a subject of scientific or geological study. Therefore, the present study was undertaken to evaluate the wetland in terms of its faunal and floral diversity as well as ecological significance for the area.

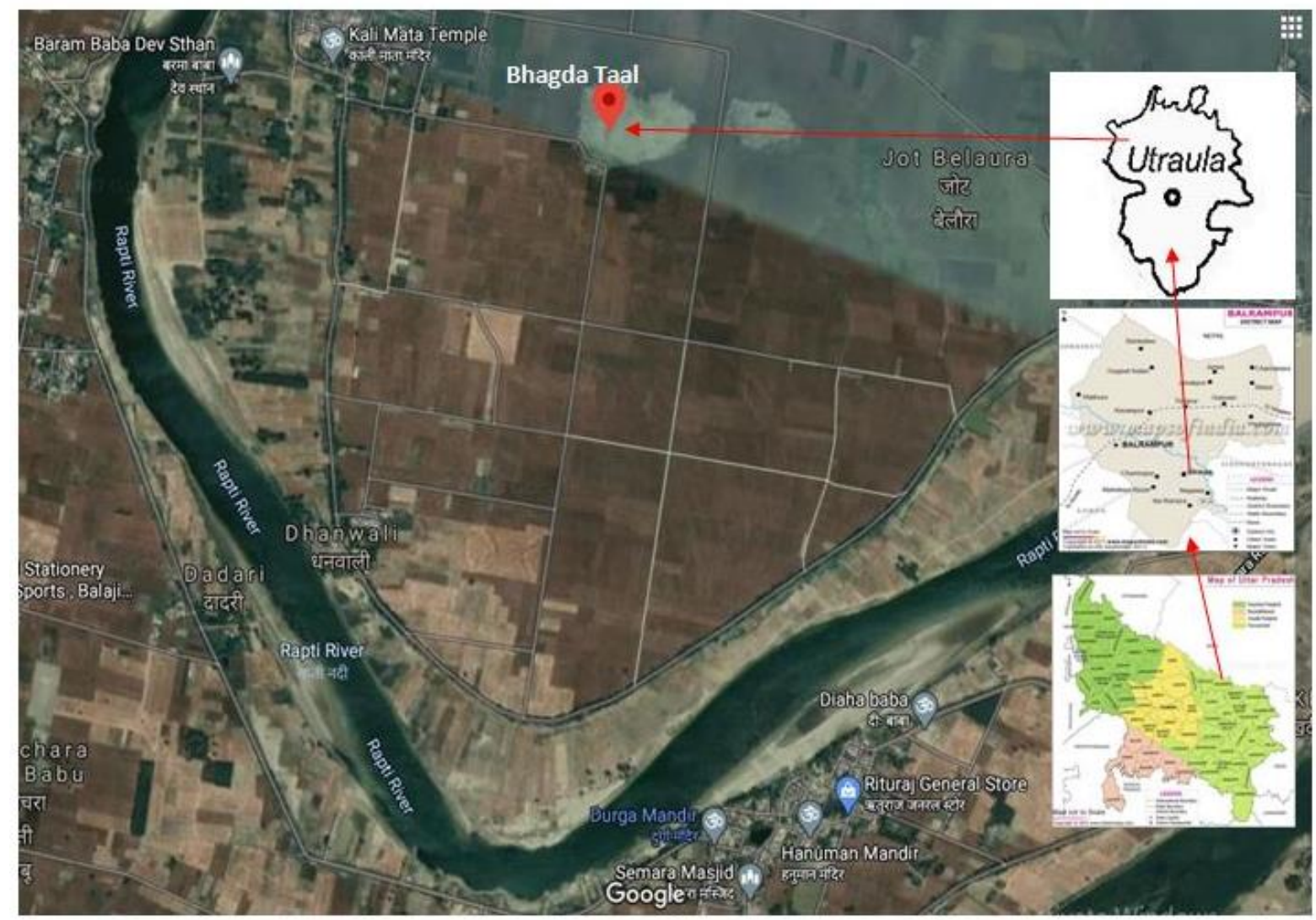

Figure: Satellite map of Bhagda Taal, Utraula Balrampur District U.P. 


\section{MATERIALS AND METHODS}

The periodical preliminary surveys of the Bhagda Taal were carried out during the year 2019 by following standard methods (Moll and Vijaya, 1986; Rao and Singh, 1987; Burbridge, 1994; Statzner et al, 1994). Standard methods of specimen collection, identification and preservation were followed to record the information. Fishes were identified using the standard keys of Jhingran (1991) and Srivastava (1998) and Dutta (2007). Dinesh et $a l$, (2017) helped to identify the amphibians while reptiles were identified with the help of Aengals (2012). Birds were identified with the help of Ali (1988). People of local communities of adjoining areas also assisted the authors in many ways for collection, identification and hospitality.

\section{RESULTS AND DISCUSSION}

In the present preliminary survey, faunal diversity comprises annelids (6 species), arthropods (16 species), molluscans (6 species), fishes (21 species), amphibians ( 3 species), reptiles ( 2 species) and birds (3 species) and zooplanktons where as the floral diversity includes 31 hydrophytes. Out of 31 species, 7 belonging to floating weeds, 3 to emergent weeds, 8 to submerged weeds, 8 to marginal weeds and 5 species of green algae and phytoplankton.

\section{FAUNAL DIVERSITY}

The Bhagda taal is rich in faunal as well as floral diversity. Besides several microscopic zooplankton (belonging to Protozoa, Rotifera and Crustacea) annelids, arthropods, molluscans, fishes, reptiles, birds and mammals have also been observed in and around the taal as given in the table 1 .

Table 1:

\begin{tabular}{|c|c|c|}
\hline Phylum/Class & Class / Order & Genus \\
\hline \multirow{4}{*}{ Annelida /Clitellata } & Oligochaeta & Tubifex (Sludge worm) \\
\hline & Arhynchobdellida & Poecilobdella (Indian freshwater Leech) \\
\hline & Rhynchobdellida & Glassiphonia, Batracobdella and Hemiceclepsis (Leech) \\
\hline & Haplotaxida & Limnodrilus (Red worm) \\
\hline \multirow{2}{*}{ Arthropoda /Crustacea } & Copepoda & Branchiura (Fish lice) \\
\hline & Amphipoda & Gammarus \\
\hline \multirow{5}{*}{ Arthropoda /Insecta } & Diptera & Chironomus, Eristalis, Diamesinae \\
\hline & Trichoptera & Hydroptila(Macrocaddisflies) \\
\hline & Hemiptera & Notolecta, Gerris, Hebrus, Ranatra \\
\hline & Coleoptera & Dineutus, Laccophilus, Cybister \\
\hline & Odonata & Acisoma, Ischnura, Agrioneais \\
\hline Mollusca/ Gastopoda & Mesogastropoda & Thiara, Pila, Lymnaea, Melanoides \\
\hline Mollusca/Bivalvia & Eulamellibranchia & Unio, Carbicula \\
\hline \multirow{7}{*}{$\begin{array}{l}\text { Chordata (Vertebrata)/ } \\
\text { Actinopterygii (Fishes) }\end{array}$} & Cypriniformes & $\begin{array}{l}\text { Catla catla, Labeo rohita, Labeo calbasu, Cirrhinus mrigala, } \\
\text { Puntius ticto, }\end{array}$ \\
\hline & Siluriformes & $\begin{array}{l}\text { Mystus seenghala, Mystus vittatus, Wallago attu Clarias batrachus, } \\
\text { Heteropneustes fossilis, Pangasius pangasius, Ailia coila, }\end{array}$ \\
\hline & Ophiocephaliformes & Channa punctatus, Channa marulius, \\
\hline & Perciformes & Anabas testudenius, Colisa fasciatus, \\
\hline & Clupiformes & Notopterus notopterus, Notopterus chitala, Gudusia chapra, \\
\hline & Belanoformes & Xenentodon cancila, \\
\hline & Synbranchiformes & Mastacembelus armatus \\
\hline $\begin{array}{l}\text { Chordata (Vertebrata)/ } \\
\text { Amphibia }\end{array}$ & Anura & $\begin{array}{l}\text { Rana trigina (Indian bull frog), Bufo melanostictus (Common Indian } \\
\text { toad), }\end{array}$ \\
\hline $\begin{array}{l}\text { Chordata (Vertebrata)/ } \\
\text { Reptilia }\end{array}$ & Testdines & $\begin{array}{l}\text { Chitra indica (Indian narrow-headed soft shell turtle), Testudo } \\
\text { graeca Tortoise }\end{array}$ \\
\hline \multirow{2}{*}{$\begin{array}{l}\text { Chordata (Vertebrata)/ } \\
\text { Birds (Aves) }\end{array}$} & Gruiformes & $\begin{array}{l}\text { Antigone (Sarus crane) and sometimes migratory bird, Leucogeranus } \\
\text { (Siberian crane) in winter season only. }\end{array}$ \\
\hline & Pelecaniformes & Heron ( Indian Egret) \\
\hline
\end{tabular}




\section{Floristic Diversity}

The Bhagda taal has rich floristic diversity. Besides microscopic phytoplankton (belonging to Chlorophyceae, Bacillariophyceae, Cyanophyceae and Euglenophyceae) several angiospermic hydrophytes have also been observed in and around the taal as follows:

\section{Floating Weeds}

Azolla, Eichhornia, Pistia, Spirodela, Wolffia, Lemna and Hygrorhiza

\section{Emergent Weeds}

Nymphaea (Lotus), Nelumbium and Nymphoides

\section{Submerged Weeds}

Hydrilla, Chara, Vallisneria, Nagas, Nitella, Ceratophyllum, Utricularia and Potamogeton.

\section{Marginal Weeds}

Typha, Cyperus, sphagnum, Jussiaea, Colocasia, Euhydra, Ipomoea and Saggitaria.

\begin{abstract}
Algae
Spirogyra, Pithophora, Microsystis, Oscilatoria and Anabaena.

Considering the importance, causes, and consequences of loss of this highly productive ecosystem with rich biodiversity, it seems better to protect and conserve the Bhagda Taal. The conservation is necessary because loss of a regional wetland not only accounts for the loss of biodiversity but also disturbs the biotic constitution and geo-climatic balance of the region. All these finally may lead to non-sustainability and natural disasters. However, biodiversity at genetic, species, and ecosystem levels is the product of long evolutionary process in prevailing eco-climatic conditions, and their loss is indeed the loss of time and space which is irreversible. Looking on the biodiversity of the taal, it is urgently needed to preserve this wetland so as to offer a natural abode to the animals, a beautiful habitat to the plants and ecological gift to the environment. The survey report therefore, suggests the importance for the conservation and sustainable utilization of Bhagda taal of Balrampur in the greater interest of nature and humanity.
\end{abstract}

\section{ACKNOWLEDGEMENT}

Authors are grateful to Principal and management committee, M.L.K. (P.G) College, Balrampur (U.P.) for providing necessary laboratory facilities.

\section{REFERENCES}

Barbier E.B., Acreman M.C. and Knowler D., 1997. Economic Valuation of Wetlands: a Guidefor Policy Makers and Planners. Ramsar Convention Bureau, Gland, Switzerland.

Costanza Robert, d'Arge Ralph, deGroot Rudolf, Farber Stephen, Grasso Monica, HannonBruce, Limburg Karin, Naeem Shahid, O’Neill Robert V, Paruelo Jose, Raskin Robert G., Sutton Paul and Belt Marjan van den, 1997. The Value of the World's EcosystemServices and Natural Capital. Nature, 387: 253-260.

Mitsch W.J. and Gosselink J.G., 1993. Wetlands. $2^{\text {nd }}$ Edition, Van Nostrand Reinhold, New York, pp. 6-8.

Prakash S., 2020a. Fish diversity of Semara Taal, A Wetlandof District Siddharthnagar (U. P.), India. International Journal of Fisheries and Aquatic Research, 5(2): 7-9.

Prakash S., 2020b. Conservation Status of Fishes of Semara Taal, A Wetland of District Siddharthnagar (U. P.), India. International Journal of Fauna and Biological Studies, 7(3): 21-24.

Prakash S., Verma A.K. and Prakash S., 2015. Limnological Studies of Alwara Lake of Kaushambi (U.P.). International Journal on Biological Sciences, 6(2): 141-144.

Prakash S. and Singh D., 2019. Limnology of Baghel taal, a wetland of district Bahraich (U.P.). IRE, 3(3): 151-158.

Prakash S. and Verma D.R., 2019. Preliminary Studies on Diversity of Aquatic Insects in Guthia Taal,a Wetland of district Bahraich, U.P. International Journal of Biological Innovation, 1(2): 78-82. DOI: https://doi.org/10.46505/IJBI.2019.1208

Prakash S. and Yadav D., 2020. Ichthyofaunal diversity of Guathia taal, a wetland of district Bahraich, U.P. (India). International Journal of Fisheries and Aquatic Research, 5(3): 38-41.

Ranjan R. and Kushwaha A., 2020. Seasonal variation in Primary Productivity and Macrophytes of Guthia Taal, Bahraich (U.P.). International Journal of Biological Innovations, 2(2): 236-240. https://doi.org/10.46505/IJBI.2020.2221 
Smitha Ajay D. and Shivashankar P., 2013. Physico Chemical Analysis of the Freshwater at River Kapila, Nanjangudu Industrial Area, Mysore, India. J. Env. Sc., 2(8): 59-65.

Verma A.K. and Prakash S., 2018. Qualitative and quantitive analysis of macrozoobenthos of
Beghel Taal, a wetland of U.P. Indian Journal of Biology, 5(2): 127-130.

Verma A.K. and Prakash S., 2020. Limnological studies of Semara Taal, a wetland of district Siddharthnagar, Uttar Pradesh, India. Journal of Fisheries and Life Science, 5(1): 15-19. 